\title{
DESCRIPTIONS OF FIVE NEW SPECIES OF VESPOID WASPS (HYMENOPTERA)
}

\author{
BY RAYMOND ROBERTS \\ University of Nebraska, Lincoln, Nebr.
}

While working on a taxonomic study of the superfamily Vespoidea, the writer has discovered a number of species that are new to science. Following are descriptions of, and comments on five new forms, the type specimens of all of which are in the collection of the University of Nebraska. Acknowledgment is made of the assistance of Professor Myron H. Swenk in the progress of this work and for criticisms in the preparation of this paper.

\section{Paratiphia magna n. sp.}

․ Length $13 \mathrm{~mm}$. Robust. Black, covered with yellowish pubescence. Face below the antennæ wide, transverse at the apex, with a distinct frontal ridge running completely across between the eyes. Clypeus and mandibles red, the mandibles black on their apices. Antennæ black. Head roughened on the vertex, but only slightly reticulated. Punctures large, dense on the lower half of the front, sparse on the upper half. Puncturation of the dorsal surfaces of the pronotum sparse, more dense on the sides, the punctures becoming quite dense on the pleural surfaces of the pronotum, which are reticulated but not striated. A broad impunctate band on the posterior border of the pronotum extending to the tegulæ at the sides. Mesonotum, scutellum and metanotum sparsely punctate on a median area. Wings hyaline, the stigma and first nervure black, the remaining nervures rufous. Tegulæ red. Legs deep reddish, the tibiæ of the mesothoracic and metathoracic legs flat on their outer 
surfaces and coarsely spined. Propodeum coarsely striated on the entire pleural surfaces. Dorsal surface of the propodeum with a triangular area, the entire area raised and not bearing a central keel. Abdominal segments 2 to 5 bordered with a fringe of coarse golden hairs. Pygidium finely, densely, rugose papillose on the entire apical half.

Holotype.-Pocatello, Idaho, “73”, ॰.

This species agrees quite closely with the description of $P$. robusta Cameron, but differs in the puncturation, being more sparsely punctured on the pronotum and on the pleural surfaces of the entire thorax. There is a broad impunctate area in the center of the mesonotum extending back to the apex of the scutellum, as in $P$. robusta, but there is no impunctate lateral border. The pleural surfaces of the thorax are reticulated but not striated. The wing veins of $P$. robusta are described as being entirely black while those of $P$. magna are rufous. Cameron states that the pygidium of $P$. robusta is smooth, but the writer has not seen a species of Paratiphia in which the female has a smooth pygidium.

Sapyga interrupta $n . \mathrm{sp}$.

9. Length $13 \mathrm{~mm}$. Black. A line extending from the middle of the inner orbits of the eyes upward to and practically filling the emarginations, a short line on the cheeks behind the eyes, an interrupted band on the anterior edge of the prothorax, a spot on the upper part of the mesopleura, two small dots on the metanotum, an interrupted dorsal band on abdominal segments $2,3,4$ and 5 and a dorsal spot on abdominal segment 6, yellow. Two small ventral spots on abdominal segment 2 and a ventral band on the following segments, interrupted on 4, yellow. Mandibles black. Antennæ black above, rufous beneath, except on the first three and last five segments. Antennæ set into deep frontal grooves. Front elevated, bearing a distinct transverse ridge slightly above its junction with the clypeus, below which it is constricted to make the clypeus narrowly joined to the front. This constricted frontal area is flat 
and depressed on either side of a median ridge extending from the transverse frontal ridge to the clypeus, the two ridges forming a rough $\mathrm{T}$. This flat, depressed, frontal area bears three transverse rows of punctures. Legs black to tips of femora, except the front legs which have a long yellow femoral stripe beneath, extending over half of the length of the femora. Middle and hind tibiæ entirely yellow, fore tibiæ marked with black. Tarsi rufous, darker toward the apices. Wings dusky violaceous, darker on the anterior edge of the front wing.

Holotype.-Pikes Peak, Colorado, July 20, 1906, 10,000 feet elevation (L. Bruner), $q$.

Sapyga interrupta most closely agrees with the characterization of Sapyga americana Cresson, as given by him in his key to the North American Species of Sapyga (Trans. Amer. Ent. Soc., viii, p. xx). It differs from that species, however, in having the clypeus immaculate. The writer has not had the opportunity of examining specimens of Sapyga americana, which species Cresson described from a specimen from New York State, but Sapyga interrupta differs from all specimens that he has identified, except the following, in having medially interrupted (not complete) yellow bands on dorsal abdominal segments 2 to 5 . The first dorsal abdominal segment is unmarked, while segment 6 bears a complete, transverse, broad yellow band. The ventral surface of the abdomen also bears yellow markings on each segment except the first.

\section{Sapyga russellensis $n$. sp.}

․ Length $10 \mathrm{~mm}$. Black. A small spot on each side of the clypeus, a line extending from the middle of the inner orbits of the eyes upward and practically filling the emarginations, a small dorsal spot on each side of abdominal segment 2 , with dorsal bands on segments 3 to 6 , narrowly interrupted on 3 and 4 , more widely interrupted on 5 , yellow. The clypeus joined to the front a little below the frontal ridge, there being but a single transverse row of 
large punctures on the constricted, flat, depressed frontal area below the frontal ridge and between it and the junction of the front and clypeus. A distinct ridge extends from the frontal ridge to the attachment of the clypeus, the two ridges forming a rough $\mathrm{T}$. All legs, except a short stripe on the fore femora, black to the tibiæ. Tibiæ black beneath, yellow above. Tarsi yellow at the bases, almost black at the apices. Wings hyaline, somewhat cloudy in the marginal cell. Stigma rufous, nervures black. Antennæ black on bases and apices, rufous in the center.

Holotype.-Russel, Colorado, June 25, 1907 (L. Bruner), $q$.

Sapyga russellensis is related to Sapyga emarginata Cresson, but lacks the emargination of the second dorsal abdominal segment. The clypeus bears a small dot on each side near the superior angles instead of a crescent-shaped spot. Sapyga russellensis can easily be separated from Sapyga interrupta by its being considerably smaller, having the bands of dorsal abdominal segment 2 reduced to mere dots, and the presence of black stripes on the tibiæ. It can also be easily indentified by the shorter, less punctured constricted area of the front.

Eusapyga intermedia n. sp.

\&. Length $10.5 \mathrm{~mm}$. Black. Mandibles except apices, apical three-fourths of the clypeus, an inverted T-shaped mark on the front above the clypeus, the inner and hind orbits of the eyes to the tops of the eyes (leaving only the tops of the eyes black), a spot on each side of the head on top, a broken anterior and complete posterior collar on the pronotum, spots on the scutellum and metanotum, a large part of the mesopleura and propodeum, and wide bands on all dorsal abdominal segments near the posterior margin and on all but the first ventral abdominal segment, yellow. Antennæ red. The clypeus joined broadly to the front and with no transverse frontal ridge present, in which characters it differs from the species of Sapyga. Legs with coxæ and trochanters entirely black, the hind femora black 
except an anterior apical spot, the middle femora with the anterior side and the anterior femora with the posterior side, yellow. Middle and hind tibiæ marked on the inner side with black, the anterior ones entirely yellow. Tarsi rufous, yellow at bases. Head with the raised spots smaller and the ocelli larger than in other species of the genus which the writer has studied, the spots being slightly larger than the ocelli. Wings clouded, stigma rufous, nervures black.

\footnotetext{
Holotype.-Auburn, California, August 10, 1918 (L. Bruner), 9 .

This species may easily be distinguished from all others described up to the present time by having the raised impunctate spots on the front small, and by the larger size of the ocelli, they being, in this species, about equal in size to the raised impunctate spots.
}

\section{Myrmosa bradleyi n. sp.}

o. Length $11 \mathrm{~mm}$. Black, clothed with black pubescence. Palpi black, covered with short white pubescence. Mandibles black with a slight reddish tinge in the center, with three teeth, the inner one of which is very short, the second one extending two-thirds of the distance from the first to the tip of the third. Both of the first two teeth are weak, the third tooth is strong. Pubescence on the mandibles long, light colored toward the tips. Scape of antennæ pubescent, bearing a number of long black hairs, the pedicel about one-fourth as long as the first segment of the flagellum, the flagellar segments subequal in length, the apical segments becoming slightly longer. Clypeus flat. A frontal ridge extending forward between the antennæ and connecting with the clypeus. Head densely punctate with large, shallow punctures. Punctures on prothorax, scutellum and metanotum similar to those on the head. There are two subparallel lines on the mesonotum and a deep groove at the base of the scutellum. Dorsal surface of the propodeum with a longitudinal groove crossed by a transverse ridge at about two-fifths of the distance from the base, and separating the dorsal from the posterior sur- 
face of the propodeum. Punctures on the propodeum smaller but continuing in abundance. Wings clouded, stigma and nervures black. First segment of the abdomen with a recurved hook, segment 2 with a minute hook at the base. Pygidium grooved above on the apical half.

Holotype.-Sacramento, California, August 25, 1916 (L. Bruner), of .

Dr. J. Chester Bradley mentioned this species, of which he had a broken specimen, in a paper on the North American Myrmosidae (Trans. Amer. Ent. Soc., xliii, p. 251). He did not name and describe the species, due to the fact that the head was lacking on his specimen.

Myrmosa bradleyi may be easily separated from Myrmosa unicolor Say by the difference in size (bradleyi 11 $\mathrm{mm}$., unicolor $8 \mathrm{~mm}$.), in the much darker wing color of bradleyi, and in the difference in the coloration of the pubescence. 

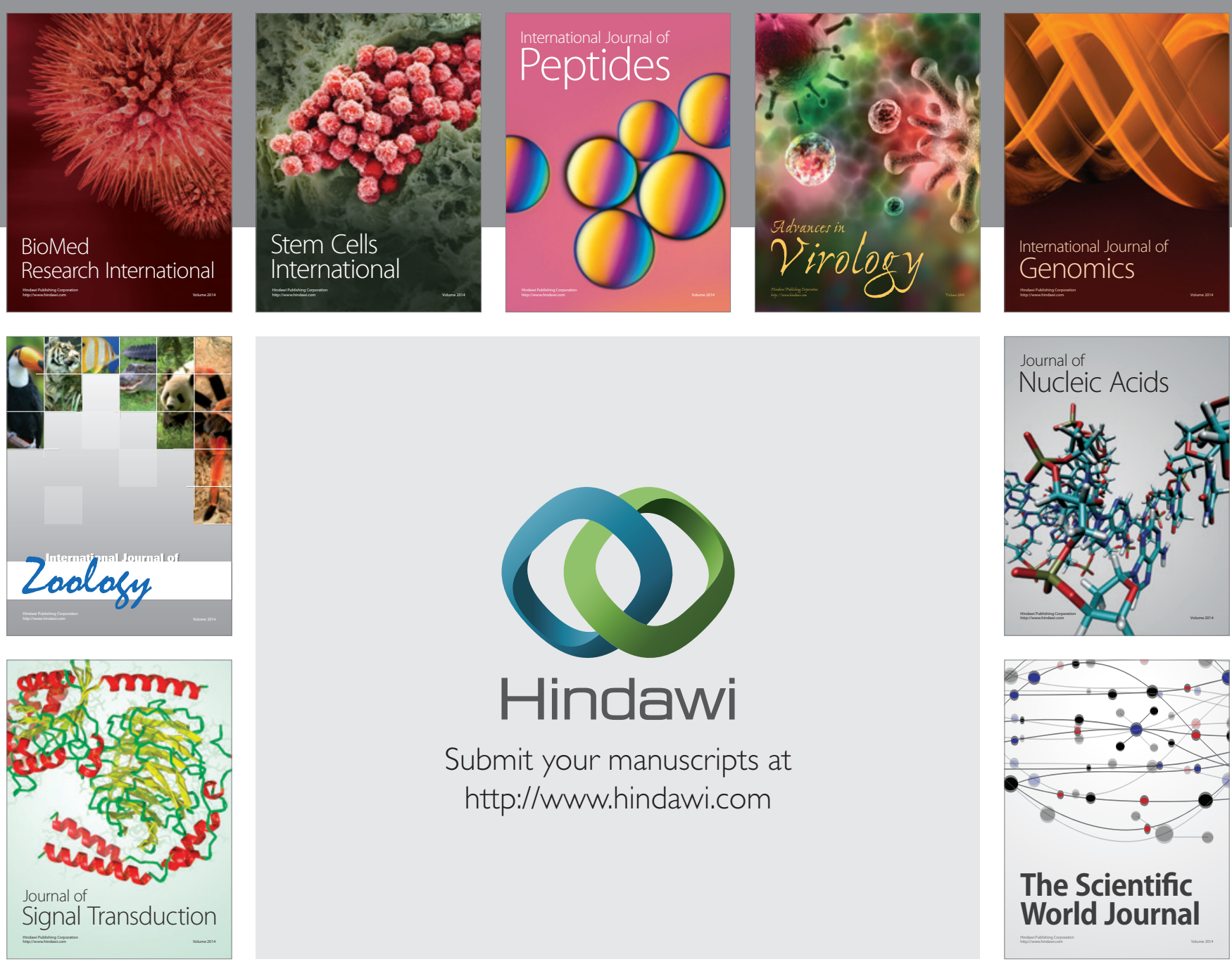

Submit your manuscripts at

http://www.hindawi.com
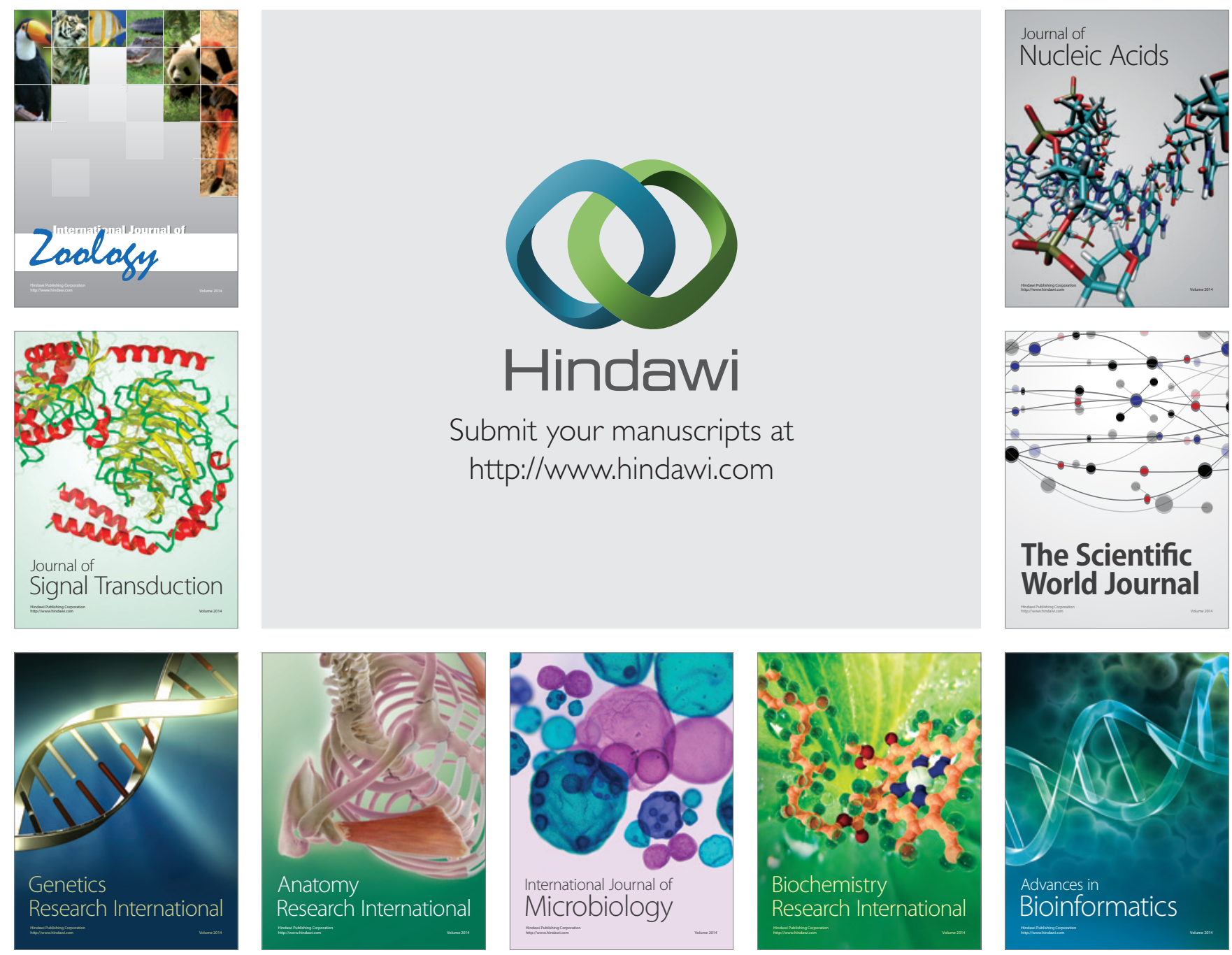

The Scientific World Journal
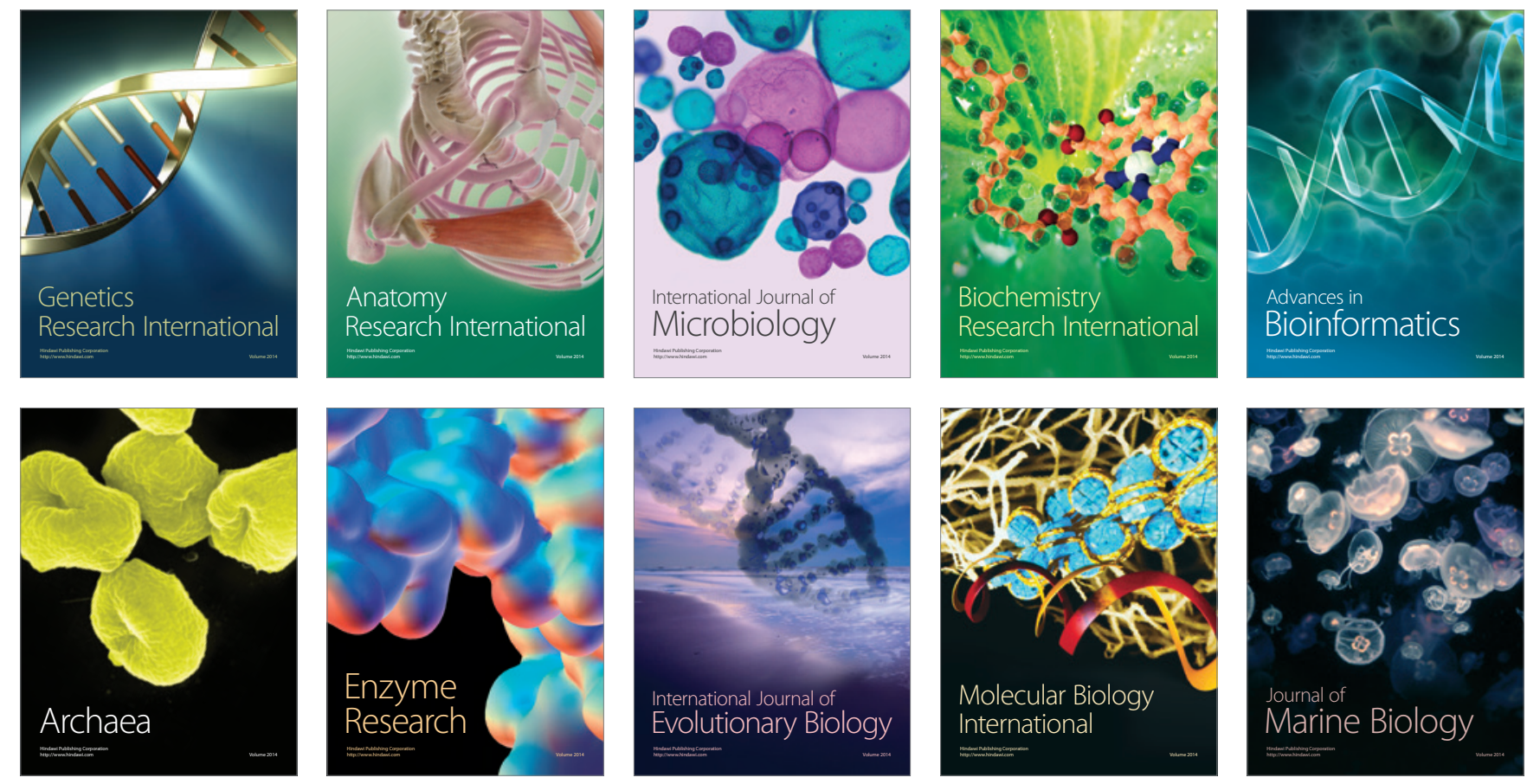